NGTT Deel 54, Nommers $3 \& 4$, September en Desember 2013

Van Rooi, Leslie

Stellenbosch University

\title{
What is in a name? Lessons learnt from the choice of name for the Uniting Reformed Church in Southern Africa
}

\begin{abstract}
The establishment of the Uniting Reformed Church in Southern Africa in 1994 was pre-empted by conversation and debates about what the name of this new church should be. In the end the selected name of this church was deliberate in the sense that it gives an ecclesiological expression of the identity of this church. As such these synodical and congregational conversations about the name of the URCSA are of church historical worth not only for the mentioned church but for churches across the globe.

In the light of processing reunification within the family of Dutch Reformed Churches it is time to revisit this decision and choice of the name, URCSA, not only because of the obvious relevance of this conversation but because the ecclesial identities of the churches that form part of the unification discussions needs to be understood and studied on the road to structurally expressions a united identity.

In this article I point towards the reasoning behind the choice of name. Mention will be made of the theological significance of this name despite of various misinterpretations and uncertainties on a local congregational and perhaps also ecumenical level. As such this article attempts to influence the current church historical debate linked to the process of re-unification in the mentioned church family.
\end{abstract}

\section{INTRODUCTION}

After recent conversations with ministers and theologians of the Uniting Reformed Church in Southern Africa (URCSA) and the Dutch Reformed Church (DRC) about the name of the URCSA and the possible options for the name of the new united ${ }^{1}$ church, I was prompted to think about and re-appreciate the name of the URCSA. As this article will point out, the relevance of this conversation and indeed a church historical study on the name URCSA and the ecclesial identity behind this name is timeously and needed as it will positively influence and stimulate ecclesiological debates and studies on church unification processes not only in South(-ern) Africa but also on a global level. The URCSA came about through the unification between the largest part of the Dutch Reformed Church in Africa (DRCA) and the former Dutch Reformed Mission Church (DRMC) in 1994. The URCSA forms part of the so-called family of Dutch Reformed Churches. ${ }^{2}$

During our conversations it became clear that there are congregations who struggle to use the name Uniting Reformed Church in Southern Africa or even the abbreviation, URCSA. Members of various local congregations rather refer to themselves as congregants of the Dutch church

1 Own Italics.

2 The term family of Dutch Reformed Churches is used to describe the historical relation between the Dutch Reformed Church (DRC), the DRCA, the URCSA and the Reformed Church in Africa (RCA). In some ecclesial circles the use of this term is contested but in the context of this article it is intended to express the interrelatedness between the abovementioned churches. 
NGTT: Oopbron - http://ngtt.journals.ac.za

or the Sendingkerk or even the NG Kerk as a way of indicating to others in their communities to which church and/or congregation they belong. ${ }^{3}$ This prompts her to question why the name (of the) URCSA is not used by her congregants? Is the name perhaps just not attractive enough and/or does it lack a strong symbolic feel? Is it due to these reasons that the particular congregants rarely make use of the name (of the) URCSA either in its abbreviated form or in full? In his historical study of the unification between the DRMC and the DRCA Loff adds to this discussion when he states that the rich meaning of the church name and the excitement of synod around it somehow did not filter through to local congregations and that variations of the name, URCSA, exist. ${ }^{4}$ This shows to the possibility that, both on a historical level and in the current sense, the name URCSA might not have been used due to the fact that it was new or even because it is not historically linked to the identity of the church. Or even due to the fact that some members do not find an obvious link between their ecclesial experience and with the name URCSA.

Although it is uncertain whether the mentioned occurrences are unique or isolated to certain congregations and/or regions or whether the examples cited by Loff exists widely, I am of the opinion that it calls for both a rediscovery and a re-evaluation of the name (of the) URCSA. This is a valuable discussion in the light of the current process of church re-unification, albeit slow moving, between the churches within the family of Dutch Reformed Churches. A study on the name, URCSA, and its linked relevance to the mentioned process will as such form the central theme of this article.

What will be pointed out in this article is that the name of the URCSA came about as a deliberate attempt to express the theological identity of this church and as such was not just selected without thorough consideration. The name is thus a deep ecclesiological expression of the identity of the URCSA and as such has a deep-rooted theological relevance.

The following section is a short discussion of the different facets of the name URCSA and why this church decided on its particular name.

\section{WHY THE NAME URCSA?}

When the DRMC and the largest part of the DRCA decided that they cannot but unite the church structures of these churches, they had to decide on the name for this 'new' church. From a church historical perspective it seems that the first formal synodic discussion on the name of the 'new' church took place at the 1986 synod of the DRMC. ${ }^{5}$ As noted in the acts of synod it is clear that the members of synod realised that a conversation on the name of the church had theological implications and as such the issue of the name was referred for further

\footnotetext{
3 Own italics. The term Dutch has been used over decades by members of the DRCA. In the same sense members of the former DRMC has referred to themselves as congregants of the NG Kerk.

4 Chris Loff, Bevryding tot Eenwording. Die Nederduitste Gereformeerde Sendingkerk in Suid-Afrika 18811994, 279.

5 From the 1986 DRMC acts of synod it is clear that, although it was not the first time that a name for the 'new' church was discussed it was the first formal and indepth discussion. See Acta Synodi, DRMC, 1986, 84. This can perhaps be connected to the fact that the the process of unification was gathering strong momentum after a slow start from 1975-1982. The work of the Joint Commission for Dialogue for Church Unity betweent he DRMC and the DRCA in later used took forward, amongst others, a discussion on the name of the 'new' church.
} 
NGTT Deel 54, Nommers 3 \& 4, September en Desember 2013

consideration to an applicable commission of the DRMC. ${ }^{6}$

In this regard the well-known theologian of the URCSA, Nico Smith, notes the following:

\begin{abstract}
“Oor die naam van die kerk wat tot stand sou kom, was daar gelukkig geen bepaalde sentimente aan 'n spesifieke naam gekoppel nie. Daar is besluit dat die gereformeerde karakter van die kerk aangedui moes word en dat dit nie 'n verenigde kerk sou wees nie, maar 'n 'verenigende kerk.' Só sou uitdrukking gegee word aan die begeerte van die twee kerke wat reeds verenig was om ook die ander kerke van die NG Kerk-familie by die vereniging te betrek. Omdat die NG Kerk ook kerke in ander lande in Suider-Afrika tot stand gebring het, moes die naam ook uitdrukking gee aan die begeerte om die kerke in ander lande in Suider-Afrika by hierdie vereniging te betrek. Daarom is die naam die Verenigende Gereformeerde Kerk in Suider-Afrika (VGKSA) gekies.?
\end{abstract}

Smith's interpretation of why the 'new' church decided on its name deeply expresses the URCSA sentiment and understanding of its ecclesiological identity as a church and as such the name is not just a name, but a deliberate attempt to show who the URCSA is and who it should be in relation to other churches and specifically to those churches within the family of Dutch Reformed Churches, as well as its context. Or, as the acts of the constituting synod of the URCSA states: '(D)ie voorgestelde naam van die Eenheidskerk is voorlopig en probeer uitdrukking gee aan die uiteindelike doelwit wat nagestreef word.8 As such it is also clear that the parts of or the full name of the URCSA was seen as temporary and that it should change when the process of reunification reached its end. This should be taken into account in the current process and should specifically be remembered when discussion on the name of the united church starts. ${ }^{9}$

\title{
3. UNITING AND NOT UNITED?
}

As many historical studies of the former DRMC and the DRCA have pointed out, the establishment of the URCSA was an expression of a longing re-unification of these churches with all the churches within the family of Dutch Reformed Churches. ${ }^{10}$ Historical synodical acts and other documents of the 1975 synod of the DRCA and the 1987 synod of the DRMC

6 "Die Hoogeerwaarde Sinode besluit om, weens die wye implikasies van 'n naamsverandering van die NG Sendingkerk, die saak na die Leer en Studiekomissie te verwys vir deeglike studie met verslag aan die volgende sinode en dat gemeentes gevra word om hul insette by die kommissie te maak." See Acta Synodi, DRMC, 1986, 903.

7 Nico Smith, Mosaïek van Mense. Ontmoetings wat my denke en lewe radikaal verander het. 303-304.

8 Acta Synodi, URCSA, 1994, 27.

9 Own italics.

10 For a good overview of the recent history of the DRMC and the DRCA and the road to unification see Daniëls, W.J. 1998. Van Sendingkerk tot Verenigende Gereformeerde Kerk in Suider-Afrika (19601997). Unpublished Master's Thesis. Cape Town: University of the Western Cape; Loff, C.J.A. 1998. Bevryding tot Eenwording. Die Nederduitse Gereformeerde Sendingkerk in Suid-Afrika 1881-1994. Published Doctoral Dissertation. Kampen: Theologische Universiteit van de Gereformeerde Kerken in Nederland; Adonis, J.C. 2002. 'Bevryding tot Eenwording en Getuienis. Die Geskiedenis van die Verenigende Gereformeerde Kerk in Suider-Afrika'. In P. Coertzen (red.), 350 Years Reformed. 16522002. Bloemfontein: CLF Uitgewers; Smit, D.J. 2002. 'Bely en beliggaam'. In P. Coertzen (red.). 2002, 350 Years Reformed. 1652-2002. Bloemfontein: CLF Drukkers. 357-371; Van Rooi, L.B. 2007. 'Bevry om te bely en te beliggaam. 'n Ekklesiologise besinning oor die Kerkorde van die VGKSA'. In the Dutch Reformed Theological Journal (NGTT). 48 no. 3\&4. Sept \& Dec 2007. 799-810. 
NGTT: Oopbron - http://ngtt.journals.ac.za

pointing towards the desire of these churches to reunite with the other churches within the family of Dutch Reformed Churches should be read against the backdrop of the theological rejection of apartheid as it found expression in the structures of the mentioned churches. ${ }^{11}$

“Ons konstituerende sinode het saam op 'n nuwe naam besluit, en dié naam getuig van die oortuigings wat sedertdien by ons leef. Ons naam sê ons is die Verenigende Gereformeerde Kerk in Suider-Afrika omdat ons weet dat die proses van kerkeenheid tussen ons nie klaar geloop is nie. Ons weet ook dit is maar die begin van 'n groter proses in ons gereformeerde familie en selfs verder. Die vereniging sal ook nie klaar wees voordat ons en die res van ons kerkfamilie sigbaar een geword het nie. Die amptelike VGKSAembleem dra hierdie selfde getuienis. Die sirkel rondom die simbole in die kerk van ons embleem is nie geslote nie, juis omdat ons inklusief dink en nog nie almal sigbaar bymekaar is nie."12

As mentioned in the previous section the constituting synod of the URCSA viewed the name of the 'new' church to give temporary expression of what this church wanted and should be. ${ }^{13}$ It can be assumed that this rings specifically true for the word, uniting, in the name of the church and that the united church would bare the name, united. ${ }^{14}$ Synod saw the process of reunification as something that had to be completed. ${ }^{15}$ This was already clearly expressed by the 1986 joint declaration by the synods of the DRMC and the DRCA that states that this unity must come to realisation and that one institutional structure should be the outcome. ${ }^{16}$

As briefly mentioned in the previous section Chris Loff notes that, on a local or congregational level, the name, uniting, was perhaps not valued. He cites examples of congregations and official church documents that at a stage in the history of the URCSA made use of the word, united, and not uniting as part of the URCSA's name. ${ }^{17}$ Perhaps this shows towards an undervaluing of the significance of the use of the word uniting in the name of the URCSA.

11 The theological importance of the mentioned synods on the road to church reunification cannot be underestimated. See the following sources for an overview of the mentioned synodical decisions as well as its tholeogical impact see Acta Synodi. DRCA. 1975; Acta Synodi. DRMC. 1978. These synods denounced the theological justification of apartheid and as immediate effect called the DRCA and the DRMC to strive towards church re-unification with the DRC and the RCA. See also The Bible and the relationships between races and people. A report by die Dutch Reformed

Church in Africa. 1975. Bloemfontein: N.G. Sendingpers; Lebone, M. 2002. 'Die totstandkoming van die Nederduitse Gereformeerde Kerk in Afrika: hoogtepunte en laagtepunte van die afgelope vyftig jaar'. In P. Coertzen (red.). 2002. 350 Years Reformed. 1652-2002. 277-278; Pauw, J.C. 2007. Anti-Apartheid Theology in the Dutch Reformed family of Churches. Published doctoral dissertation. Amsterdam: Vrije Universiteit Amsterdam; Van Rooi, L.B. 2008. 'To Obey or Disobey? The Relationship between Church and State during the days of Apartheid: Historical lessons from the activities of the Belydende Kring (1974-1990)'. In Studia Historiae Ecclesiasticae. July. 2008 Vol. XXXIV. No. 1. 173-179.

12 Johan Botha, Belhar - goeie nuus vir gister, vandag en more, In Johan Botha en Piet Naudé, Goeie nuus om te bely. Die belydenis van Belhar en die pad van aanvaarding, 77-78, 2010.

13 Acta Synodi, URCSA, 1994, 27.

14 Own italics.

15 "Daarmee word ook die deur vir nog meer kerke oopgehou." Acta Synodi, URCSA, 1994, 27.

16 "Die twee afvaardigings verklaar dit as hul gemeenskaplike oortuiging dat die Bybelse leer oor die eenheid van die kerk en die gereformeerde opvatting oor die sigbare eenheid van die kerk gestalte móét vind in een enkele NG Kerkverband. Dit beteken dat die bestaande institute sal moet verenig in 'n enkele instituut, georganiseer volgens gereformeerde kerkreg en kerkverband." See Acta Synodi, DRMC, 1986. 36.

17 Own italics. Loff, Bevryding tor Eenwording, 1998, 279. 
NGTT Deel 54, Nommers 3 \& 4, September en Desember 2013

Or perhaps this warns the church that its ecclesiology and specifically how it expresses this ecclesiology should be connected to and lived out through the experiences and practices in the local congregations.

\title{
4. Timeously And Reformed?
}

When reading through the synodical acts and other documents on discussions regarding the name of the 'new' church it is clear that Synod felt strongly that the reformed character of the URCSA should be expressed in its name. One almost gets the impression that the name of the 'new' church cannot but be called reformed. ${ }^{18}$ Dirkie Smit shares this sentiment when he states:

\begin{abstract}
"Toe die NG Kerk in Afrika en die NG Sendingkerk vroeg in 1994 verenig het tot die Verenigende Gereformeerde Kerk in Suider-Afrika, het die nuwe sinode, met oorweldigende entoesiasme, in 'n Verklaring van Voorneme, gesê dat hulle 'n kerk wil wees "gebou op die grondslag van die gereformeerde belydenis, tradisie en etos". Talle sinodegangers het hulle blydskap daaroor uitgespreek. In verskillende toesprake is daarop klem gelê. In die wandelgange het baie lede gesê hoe belangrik dié duidelike keuse, ja, belydenis was."19
\end{abstract}

In my view this shows towards the URCSA's understanding and valuing of its reformed heritage and that it deliberately wanted to link this heritage to its ecclesiology. The use of the word, reformed, in the name of the URCSA also shows towards a deliberate link with other reformed churches when read against the backdrop of this church's strive for unity, specifically with the other churches within the family of Dutch Reformed Churches. One could therefore ask what the effect would have been on the ongoing process of the URCSA if the word, reformed, was excluded from its name.

This being said it is not clear from synodical documents how the 'new' church interpreted its reformed character. The fact that the theological school of the URCSA was immediately asked to do a study on the reformed character of the church, shows towards the possibility that the 'new' church would start to understand and give fuller expression of its nature and identity. ${ }^{20}$ And perhaps the URCSA and the other churches within the family of Dutch Reformed Churches should again ascertain what is understood with, and how it expresses the meaning of the term, reformed, in its ecclesiology and in the practices of local congregations. ${ }^{21}$

Of note is the fact that unlike the deliberate decision of Synod to keep the word reformed

18 “Dit spreek vanself dat die kerk 'Gereformeerde' genoem sal word.” See Acta Synodi, URCSA, 1994. 27. 19 Dirkie Smit, Vraagtekens oor gereformeerde integriteit. In WA Boesak en PJA Fourie, Vraagtekens oor Gereformeerdheid, 1998, 18.

20 Smit, Vraagtekens. In Boesak en Fourie, Vraagtekens oor Gerefomeerdheid, 1998, 18. The quoted publication should be seen as one of the URCSA studies its reformed identity.

21 For a good overview of Dirkie Smit's discussions on the term Reformed see Fourie, W. 2011. 'Can we still be Reformed? A tentative consideration of the Reformed tradition and South Africa's modernity'. In Koopman, N (et al). 2011. Living Theology. Essays presented to Dirk J Smit on his sixtieth birthday. Wellington: Bible Media. In 2001 Coenie Burger wrote a popular puplication in the wake of what he and other Dutch Reformed theologians saw as an identiy crisis in the DRC around its reformed identity. See Burger, C. 2001. Ons weet aan wie ons behoort. Nuut gedink oor ons gereformeerde tradisie. Wellington: Bible Media. Perhaps this suggests that it is indeed timeous for the Reformed tradition to continuesly think about, study and evaluate its identity. 
NGTT: Oopbron - http://ngtt.journals.ac.za

in the name of the URCSA it decided not to keep the Dutch ${ }^{22}$ part of the name. The Dutch (Afrikaans: Nederduitse) in the name of the Dutch Reformed Church refers to the region where this church finds its roots and should be read as a synonym for The Netherlands or Holland. ${ }^{23}$ In my view this is an indication that the church, although linked to its reformed heritage, would through its name express that it was and wanted to be fully part of the African context. Perhaps this decision can also be connected to a deliberate attempt by the DRMC and the DRCA to break away from a paternalistic relationship between these churches and the DRC as the so-called 'mother church.'. ${ }^{24}$ Or as Themba Nyatyowa states: '(T)he newly found unification brought an end to the DRCA and DRMC churches that were founded during the Apartheid (sic) regime. The terms, "Dutch Reformed Church in Africa" and "Dutch Reformed Mission Church", were something of the past.'25 However this may be, the historical link through its reformed heritage with specifically the Dutch Reformed Church was not lost in the process albeit without the word Dutch in the name of the URCSA.

\section{IN AND NOT OF?26}

Any discussion on why the URCSA decided to be church in and not of Southern Africa should take into account the histories of the DRMC and the DRCA and here specifically their relation with the DRC as so-called 'mother church'. For the largest parts of their histories these churches struggled to reach a position of ecclesial autonomy due to a strong paternalistic grip from the DRC. ${ }^{27}$ To this should be added the fact that mission activities of the DRC was partially based on the missional thinking of Gustav Warneck who placed emphasis on the wellbeing of a specific nation or volk. ${ }^{28}$ It should be remembered that at a stage the various 'mission churches' were established for a specific cultural group and that membership was linked accordingly and as such the idea of separate churches for various nations was theologically justified. ${ }^{29}$

As the various "mission churches" started to intensify their strive towards reaching ecclesial autonomy in relation to the DRC, and as these churches developed their specific theological

\section{Own italics.}

23 PB van der Watt, Die Nederduitse Gereformeerde Kerk 1652-1905, 1988, 11. According to Scholtz this term was only used is South Africa since 1842. See, GD Scholtz, Die Geskiedenis van die Nederduitse Hervormde Kerk van Suid-Afrika. 1842-1885, 1956, 11.

24 Of interest to note is that the term Dutch Reformed Mission Church or Dutch Reformed Church (referring to the DRMC) was used until as late as 1998 on a local congregational level. See Loff, Bevryding tot Eenwording, 1998, 279.

25 Themba Nyatyowa, The unification process in the Family of Dutch Reformed Churches from 1975-1994: A critical evaluation, 1999, 80.

26 Of interest to note is the fact that in the 1994 acts of synod of the URCSA no mention is made of the reasoning behind the selection of the word in and not of. See Acta Synodi, URCSA, 1994, 27.

27 For a good overview of the DRMC and DRCA struggle to reach ecclesial autonomy see Leslie van Rooi, In Search of Ecclesial Autonomy. A church historical and church juridical study of developments in church polity in the Dutch Reformed Mission Church in South Africa (DRMC) and the Dutch Reformed Church in Africa (DRCA) from 1881-1994, 2010.

28 Van Rooi, In Search of Ecclesial Autonomy, 2010, 25-26.

29 Van Rooi, In Search of Ecclesial Autonomy, 2010, 29-37. In his discussion on pluriformity Willie Jonker shows to the planting of volks churches in various contexts internationally. He pleads for one church of Christ that knows about diversity and that this university calls for unity. See Willie Jonker. 'Die Sendingbepalinge van die Ned. Gereformeerde Kerk van Transvaal'. In Kerk en Wêreld. Nr 4. June 1962, 29. See also Jonker, WD. 1965. Om die Regering van Christus in sy Kerk. Pretoria: University of South Africa. 
NGTT Deel 54, Nommers 3 \& 4, September en Desember 2013

accents the idea of separate churches was rejected. The establishment of the URCSA and the ongoing process for reunification within the family of Dutch Reformed Churches should be understood in the light of this.

The theologically justifiable notion that ecclesial autonomy is found in the Lordship of Christ - that the church belongs to Christ - became a well-developed notion in the theology(-ies) of the DRMC and the DRCA and guided these churches in understanding and acknowledging their identities in Christ. ${ }^{30}$ This notion of Christ's Lordship is not unique to the context of the family of Dutch Reformed Churches, but takes in a central place in reformed theology and specifically in ecclesiology and church polity. As such it should be read as part of the reformed identity of the URCSA.

The Lordship of Christ as a theological concept has a direct impact on how churches understand their identity and here specifically how they relate to one another and to their social contexts. Herein I believe lies the URCSA's decision to be church in and not church of. Although the URCSA finds itself in a specific context within Southern Africa it belongs to Christ and as such can only be a particular expression of Christ's church in a specific context. Just as the URCSA does not know of geographical boundaries it does not know of separation based on language cultural, national identity, etc. and as such this understanding of being church guides the URCSA to continue its strive toward a fuller unity - a unity that in the first instance calls for the re-unification of the churches within the family of Dutch Reformed Churches. ${ }^{31}$

The debate around the use of the words, of or in, in the name of the URCSA is not unique to this church. At least two other churches who have over the last couple of decades united in regions similar to the URCSA have also had this discussion with varying outcomes, namely the United Congregational Church of Southern Africa (UCCSA) and the Uniting Presbyterian Church in Southern Africa. ${ }^{32}$ From a reformed point of view this discussion should always be guided by an evaluation of the notion of the Lordship of Christ.

\section{South Africa in relation to Southern Africa?}

From the onset the URCSA wanted to express that it cannot define itself nor fully express its ecclesiology in terms of geographical borders. In fact, it does not know any borders and this should find expression in its ecclesiology both in terms of theory and practice. As discussed in the previous section this should be read against the backdrop of the reformed notion of Christ's Lordship and its impact on how the church relates to both national boundaries and its relatedness with other churches. Although the Church does not know any borders it still proclaims the word of God in a specific context. The URCSA decided to express its identity as a particular voice of the church of Christ within the context of Southern Africa and not only South Africa. With this the URCSA clearly expresses its understanding and theological

30 Van Rooi, In Search of Ecclesial Autonomy, 2010. 250.

31 Jonker ridicules the notion of establishing identical parallel churches in the context of South Africa based on cultural differences. See Jonker, 'Die Sendingbepalinge', in Kerk en Wêreld, 1962, 30-32.

32 Own italics. For an overview of the histories of the mentioned churches see Roy Briggs and Joseph Wing. The Harvest and the Hope. The Story of Congregationalism in Southern Africa. 1970; Pieter Coertzen (ed). 350 Years Reformed. 2002. It is interesting that the UCCSA and the UPCSA decided to add the term Southern Africa to their name. It can be assumed that the rationale behind this decision is similar to that of the URCSA. 
NGTT: Oopbron - http://ngtt.journals.ac.za

conviction that national ties should not keep Christians apart. ${ }^{33}$

In a real sense the URCSA in 1994 foresaw a future where its unity would be realised with churches in other parts of Southern Africa and as such this part of its name wanted to express this hope. ${ }^{34}$ Or, as the acts of the 1994 synod states: '(T)en slotte word as aanduiding van plek nie van "Suid-Afrika" nie, maar van "Suider-Afrika" gepraat om daardeur te beklemtoon dat ons susterkerke in Suider-Afrika nie uitgesluit word by ons eenheidstrewe nie.'35 In 1997 the Evangelical Reformed Church in Africa (ERCA), with its congregations in Namibia, united with the URCSA thus guiding the URCSA in striving towards further unity with the broader family of Dutch Reformed Churches - also with those (reformed) churches outside the geographical borders of South Africa. ${ }^{36}$

Of interest to note is the hesitation of the last synod of the former DRMC to make use of the generally used reformed term 'general synod' to give expression to the larger meeting of the 'new' church. This hesitation is directly linked to two reasons, namely the historic ecclesial structures of the DRMC and the DRCA and how it will impact on a church vision in the foreseeable future as well as the fact that the'new' church will cross geographical boundaries. ${ }^{37}$ From the synodical discussions at the time one can gather that the uncertainty came about because of the fact that the term 'general synod' in the international reformed world mostly referred to a national church or the bigger church within national borders. And as such this discussion was worthwhile to have.

\section{IN CONCLUSION}

Conversations and studies on the name of a church are very relevant in the context of reformed ecclesiology and church polity. As such vibrant debates around names are prevalent not only in the family of Dutch Reformed Churches, but also in other churches in South Africa e.g. the UCCSA and the UPCSA. To this can be added the Gereformeerde Kerke as the name of this church also gives particular ecclesiological expression of its identity. ${ }^{38}$

This also rings true for the URCSA. This article points towards a clear and deliberate decision on a name that expresses the identity, character and thus the ecclesiology of this church.

33 For a good overview of synodical conversation linked to national boundaries and the unity of the church in the 1986 period see Nyatyowa, The unification process, 1999, 52.

34 It should be remembered that the through direct and/or indirect mission work the Dutch Reformed

Church had relations with a number of churches in Southern Africa as well as in other parts of the

African continent. These include churches in countries like Malawi, Zimbabwe, Zambia, Kenya, Nigeria,

Namibia, etc. Perhaps one on the most detailed overviews regarding the missional link between the Dutch

Reformed Church and other Reformed churches in the mentioned countries see JM Cronje. Aan God die

Dank. Geskiedenis van Sending buite die Republiek van Suid-Afrika. Deel 2. 1981.

35 Acta Synodi, URCSA, 1994, 27.

36 See JM Cronje. Aan God die Dank. Geskiedenis van Sending buite die Republiek van Suid-Afrika. Deel 2. 1981. 341-350; Daniels, WJ. 1998. Van Sendingkerk tot Verenigende Gereformeerde Kerk in SuiderAfrika (1960-1997). Unpublished Master's Thesis. Bellville: University of the Western Cape.

37 'Die naam van die genoemde sinode is onseker, aangesien 'Algemene Sinode' nie gebruik kan word nie omdat daar vir die voorsienbare toekoms wel nog Algemene Sinodes van die betrokke kerke sal wees, en 'Nasionale Sinode' onpresies is vanweë die feit dat twee van die 'bestaande Sinodes' (Namibië en MiddeAfrika) buite die RSA se nasionale grense lê." See Acta Synodi, DRCMA, 1994, 41.

38 For an overview of the history of the Gereformeerde Kerke see Pieter Coertzen (ed). 350 Years Reformed. 2002. 
NGTT Deel 54, Nommers $3 \& 4$, September en Desember 2013

In my view the URCSA should continuously remind itself about its name and how it came about specifically when it comes to conversation and decisions linked to its ecclesiology and how it finds expression within its congregations and in formal church meetings. In the process of reunification between the churches within the family of Dutch Reformed Churches a conversation on the name of the new church must be influenced by a deep ecclesiological discussion on who this united church will be. For this to be possible the URCSA should continuously challenge itself to rediscover its identity and, as is the case with other churches, strive to root its ecclesial identity in the day-to-day actions of local congregations and in the lives of its congregants.

If this is so then perhaps Shakespeare's renown words, 'What's in a name? That which we call a rose by any other name would smell as sweet;' might not ring true for URCSA and the other churches in the family of Dutch Reformed Churches. ${ }^{39}$

\section{BIBLIOGRAPHY}

Acta Synodi. 1986. DRMC.

Acta Synodi. 1994. URCSA.

Acta Synodi. 1994. DRMCA.

Botha, J. 2010. 'Belhar - goeie nuus vir gister, vandag en more'. In Botha J en Naudé, P. 2010. Goeie nuus om te bely. Die belydenis van Belhar en die pad van aanvaarding. 73-92. Wellington: Bybel-Media.

Cronje, JM. 1981. Aan God die Dank. Geskiedenis van Sending buite die Republiek van Suid-Afrika. Deel 2. Pretoria: NG Kerk Boekhandel.

Jonker, WD. 1962. 'Die Sendingbepalinge van die Ned. Gereformeerde Kerk van Transvaal'. In Kerk en Wêreld. Teologiese studies oor die sending van die kerk in die wêreld. Nr. 4. June 1962.

Loff, CJA. 1998. Bevryding tot Eenwording. Die Nederduitse Gereformeerde Sendingkerk in Suid-Afrika 18811994. Published Doctoral dissertation. Kampen: KOK Publishers.

Nyatyowa, T. 1999. The unification process in the Family of Dutch Reformed Churches from 1975-1994: A critical evaluation. Unpublished Master's Thesis. Bellville: University of the Western Cape.

Scholtz, GD. 1956. Die Geskiedens van die Nederduitse Hervormde of Gereformeerde Kerk van Suid-Afrika. 1842-1885. Pretoria: NG Kerkboekhandel.

Smit, DJ. 1998. 'Vraagtekens oor gereformeerde integriteit'. In Boesak, WA \& Fourie, PJA. 1998. Vraagtekens oor Gereformeerdheid. 5-19. Belhar: LUS Uitgewers.

Smith, N. 2010. Mosaïek van mense. Ontmoetings wat my denke en lewe radikaal verander het. 2010. Wellington: Bybel Media.

Van der Watt, PB. 1988. Die Nederduitse Gereformeerde Kerk 1652-1905. Pretoria: NG Kerkboekhandel.

Van Rooi, LB. 2010. In Search of Ecclesial Autonomy. A church historical and church juridical study of developments in church polity in the Dutch Reformed Mission Church in South Africa (DRMC) and the Dutch Reformed Church in Africa (DRCA) from 1881-1994. Unpublished Doctoral Dissertation. Stellenbosch: Stellenbosch University.

\section{TREFWOORDE}

VGKSA

Gereformeerd

Kerkhereniging

Belhar

Familie van NG Kerke

Key Words

URCSA

39 See Shakespeare's famous play, Romeo and Juliet https:/scholarsbank.uoregon.edu/xmlui/bitstream/ handle/1794/837/romeo.pdf? sequence $=1$ 
NGTT: Oopbron - http://ngtt.journals.ac.za

Reformed

Church Reunification

Belhar

Family of Dutch Reformed Churches

Contact details

Dr LB van Rooi

Dept Sistemtiese Teologie en Ekklesiologie

Stellenbosch Universiteit

Ibvr@sun.ac.za

0218083697 